\title{
Energy Source, Protein Metabolism, and Hunter-Gatherer Subsistence Strategies
}

\author{
JoHN D. SPETH \\ Museum of Anthropology, University of Michigan, Ann Arbor, Michigan 48109
}

AND

Katherine A. SpielmanN

Department of Anthropology, National Museum of Natural History, Smithsonian Institution, Washington, D.C. 20560

Received November 9, 1982

\begin{abstract}
During late winter and spring, hunter-gatherers in temperate, subarctic, and arctic environments often relied on diets that provided marginal or inadequate caloric intakes. During such periods, particularly when stored food supplies dwindled or were used up entirely, lean meat became the principal source of energy. Nutritional problems associated with high-protein, low-energy diets are discussed. These problems include elevated metabolic rates, with correspondingly higher caloric requirements, and deficiencies in essential fatty acids. The relative benefits of adding fat or carbohydrate to a diet of lean meat are evaluated in light of the protein-sparing capacities of these two nutrients. Experimental data indicate that although both enhance high-protein, low-energy diets, carbohydrate is a more effective supplement than fat. Given the nutritional inadequacies of a lean-meat diet, the paper concludes with a discussion of alternative subsistence strategies that increase the availability of carbohydrate or fat at the critical time of year.
\end{abstract}

\section{INTRODUCTION}

The problem of seasonal and long-term nutritional stress has received much attention in recent anthropological and archaeological research (e.g., Newman 1975; Wetterstrom 1976; Cox 1978; Hitchcock 1978; Laughlin and Brady 1978; Dirks 1980; Minnis 1981). Thus far, the focus of most studies has been on the effects of, and responses to, inadequate calorie and/or protein intake in contexts where the diet consists predominantly of carbohydrate and low levels of protein. Here we propose to examine the reverse situation: recurrent periods of moderate to severe 
caloric stress in contexts where carbohydrate intake is low, and where protein intake may at times provide as much as 85 or $90 \%$ of the total calories. In the following discussion we show that (1) many hunter-gatherers recurrently relied on protein as a principal source of calories at certain times of the year, and (2) such reliance could lead to marginal or inadequate energy intake and other nutritional deficiencies in the hunter-gatherer diet. We examine the causes of these deficiencies and suggest subsistence strategies that would buffer hunter-gatherers against such potential periods of stress.

Our concern is with periods of high lean meat (i.e., high protein) consumption, when carbohydrates and animal fat would have been scarce or unavailable to hunters and gatherers as sources of calories. We became interested in this situation when our research on late prehistoric and early historic adaptations in the Southern High Plains indicated that hunters and gatherers were adopting a variety of subsistence strategies in the late winter and spring that avoided the consumption of lean bison meat (Speth 1983; Spielmann 1982). Fat-depleted animals were avoided and lean cuts of meat were abandoned by hunters at spring-season kill sites despite the facts that spring was generally a time of food scarcity in the region and bison was the only readily available subsistence resource. To better understand this seemingly paradoxical subsistence behavior, we turned to the nutritional literature to determine if there were in fact serious problems associated with high lean meat intake that might compel hunter-gatherer populations to adopt alternative subsistence strategies.

While our original concern was with hunters and gatherers in temperate grassland environments, this discussion also applies to hunter-gatherer populations in other sharply seasonal environments (e.g., inland arctic, subarctic, northern deciduous forest). In environments such as these, late winter and spring were often times of recurrent food shortage, hunger, weight loss, and starvation (for a few ethnographic examples, see Anastasio 1972; Bean 1972; Goldschmidt 1951:417; Steward 1938:19-20, 27, 46; Kelly 1964:22; Hodge 1907:51-52; Silberbauer 1981:274-275; Gusinde 1961:284; Piddocke 1965; Balikci 1968; Grinnell 1972:258; Hayden 1981:414-415 and references therein; see also Wilmsen 1978; Truswell and Hansen 1968; Shephard 1974:287, 1980:329; Rode and Shephard 1973:172; Høygaard 1941:68 for quantified examples of seasonal weight loss in hunter-gatherers). Recent studies in paleopathology document similar periodic nutritional stress in populations of prehistoric hunters and gatherers, including those in so-called "nonmarginal" habitats (see Huss-Ashmore et al. 1982:434-450 and references therein; Buikstra 1976, 1981; McHenry 1968; McHenry and Schulz 1978; Cassidy 1972). 
In late winter and spring, reliable alternative resources such as small mammals, fish, and stored plant foods often became scarce or unavailable, and hunter-gatherers had to rely on large ungulate species for a major part of their diet. It is precisely at this time of year, however, that a diet composed largely or entirely of ungulate meat may lead to caloric and other nutritional deficiencies because the ungulates themselves are experiencing nutritional stress and becoming fat-depleted.

\section{UNGULATE CONDITION AND ITS CONSEQUENCES FOR HUNTER-GATHERER DIETS}

Male ungulates may lose up to 10 or $15 \%$ of their body weight during the fall rut due to high energy expenditure and reduced forage intake. As a consequence, they often enter winter in comparatively poor condition. If nutritional shortages occur during winter, their body-fat reserves begin to be depleted and their overall condition declines through late winter into spring. Females often enter winter with more reserves than males; their condition therefore may be somewhat better in early spring. Later in the spring, however, pregnant or lactating females decline in condition to a level below that of males. Thus, both sexes are in poorest condition in the spring, and both may have become severely fat-depleted (Allen 1979; Anderson et al. 1972; Nordan et al. 1968; Peterson 1977; Pond 1978; Riney 1955; Sinclair and Duncan 1972; Binford 1978:40).

With plant foods largely unavailable in this season, and in situations where stored carbohydrate reserves were nearly or entirely exhausted, the hunter-gatherer diet would have been composed mainly of protein with whatever fat remained in the meat. As the following ethnographic and historic accounts document, high reliance on lean meat can lead to serve nutritional stress. For example, Stefansson has described the deleterious effects of subsisting on the lean meat of rabbits in northern latitudes. These animals are notoriously low in body fat, and reliance on them for food leads to a condition known as "rabbit starvation."

If you are transferred suddenly from a diet normal in fat to one consisting wholly of rabbit you eat bigger and bigger meals for the first few days until at the end of about a week you are eating in pounds three or four times as much as you were at the beginning of the week. By that time you are showing both signs of starvation and of protein poisoning. You eat numerous meals; you feel hungry at the end of each; you are in discomfort through distention of the stomach with much food and you begin to feel a vague restlessness. Diarrhoea will start in from a week to 10 days and will not be relieved unless you secure fat. Death will result after several weeks. (Stefansson 1944:234)

Observations similar to those of Stefansson are common in the ethno- 
graphic literature. The following examples further illustrate the inadequacy, in northern latitudes, of a diet based on lean meat.

The quantity of food consumed at one meal naturally varies according to the amount of fat it contains. Men and dogs will half-starve on a diet of lean cariboumeat, however plentiful, whereas half the quantity of blubbery seal-meat will satisfy their desires and keep them well nourished. (Copper Eskimo, Canada; Jenness 1923:100)

If people had only rabbits at such times they would probably starve to death, because these animals are too lean. The same might be true if they could get only thin moose. People cannot live on lean meat alone, but if they have enough fat they can survive indefinitely. (Kutchin, Alaska; Nelson 1973:142)

There are many similar observations in the ethnohistoric literature, and these are by no means confined to the arctic. For example, Warren $\mathrm{A}$. Ferris, while trapping in the Bear River Valley of Utah in 1830, made the following observations concerning the poor sustenance provided by lean buffalo.

We killed here a great many buffalo, which were all in good condition, and feasted, as may be supposed, luxuriously upon the delicate tongues, rich humps, fat roasts, and savoury steaks of this noble and excellent species of game. Heretofore we had found the meat of the poor buffalo the worst diet imaginable, and in fact grew meagre and gaunt in the midst of plenty and profusion. But in proportion as they became fat, we grew strong and hearty. . . (Phillips 1940:42)

Jedediah Smith led a group of trappers along the Klamath River in California in May 1828. According to Dale Morgan (cited in Allen 1979:457),

... the party made only 3 miles on the 18 th, which taxed their strength to the utmost. 'The men were almost as weak as the horses, for the poor [spring] venison of this country contained little nourishment.'

Finally, Randolph B. Marcy in the winter of $1857-1858$ provided an illuminating comment regarding the inadequacy of a diet based on fatdepleted meat.

We tried the meat of horse, colt, and mules, all of which were in a starved condition, and of course not very tender, juicy, or nutritious. We consumed the enormous amount of from five to six pounds of this meat per man daily, but continued to grow weak and thin, until, at the expiration of twelve days, we were able to perform but little labor, and were continually craving for fat meat. (Marcy 1863:16)

Of particular interest are frequent references to situations in which hunters avoided or abandoned animals they considered too lean for use in favor of fatter animals, even when the hunters themselves were short of food. A typical example was recorded by Lewis and Clark in December 1804.

Captain Lewis went down with a party to hunt. They proceeded about 18 miles; but the buffalo having left the banks of the river they saw only two, which were so poor as not to be worth killing. ... (Coues 1893:211) 
In February 1805 Lewis and Clark made another, similar entry in their diary.

Captain Clark returned last evening with all his hunting party. During their excursion they had killed 40 deer, 3 buffalo, and 16 elk; but most of the game was too lean for use. ... (Coues 1893:233)

As a final example, Jacob Fowler, during his expedition to the Rocky Mountains of Colorado, made the following comment in his journal in February 1822.

Hunters out Early-Killed one Cow Buffelow With In four Hundred yards of Camp—but so Poor the meat Was not Worth Saveing. . . . (Coues 1898:97; spelling as in original)

To summarize, the above data indicate that a diet composed largely of lean meat (i.e., mainly protein with small amounts of fat), even in quantities that would appear to satisfy caloric requirements, can result in serious nutritional problems. Hunters apparently were keenly aware of the deleterious effects of a lean-meat diet, and, when possible, abandoned lean animals for fatter ones, even when they were short of food (see also Jochim 1981:81 and Hayden 1981:394-398 for discussions of the importance of fat in hunter-gatherer diets).

\section{PROTEIN METABOLISM}

The nutritional literature provides interesting insights into the reasons why diets composed largely of lean meat should have the negative effects described in the above quotes, and suggests which alternative sources of energy should be preferentially sought to supplement such a diet. We briefly review pertinent aspects of this literature to (1) delineate several key problems peculiar to meeting caloric needs under high-protein, lowenergy diets, and (2) derive a series of subsistence activity responses which hunter-gatherers may be expected to make to cope with periods of adequate protein intake but caloric deficiency.

\section{Specific Dynamic Action}

One aspect of protein metabolism relevant to this issue concerns the high "specific dynamic action" (SDA) of protein ingestion. The SDA of food refers to the rise in metabolism or heat production (diet-induced thermogenesis) resulting from the ingestion of food (Chaney and Ross 1971:45; Briggs and Calloway 1979:32; Barnes 1976:12-13; Houssay et al. 1955:455-456; Taylor and Pye 1966:39-40; Guthrie 1975:94-95; Bigwood 1972:xxii; Rothwell and Stock 1979; Wing and Brown 1979:22; Bourlière 1964:336). The SDA of a diet consisting largely of fat is about $6-14 \%$, while that of a diet high in carbohydrates is about $6 \%$. In striking 
contrast, the SDA of a diet consisting almost entirely of protein may be as high as $30 \%$; or, in other words, for every 100 calories of protein ingested, up to 30 calories are needed to compensate for the increase in metabolism. Thus, persons whose diets are high in protein experience higher metabolic rates than those whose diets are composed largely of carbohydrate. For example, members of Eskimo populations, at least $90 \%$ of whose caloric needs were traditionally met by meat and fat (cf. Draper 1980:263; Høygaard 1941), had basal metabolic rates 13 to $33 \%$ above the DuBois standard, which is based on the metabolic rates of populations consuming western diets (Itoh 1980:285).

In a series of experiments, Long (1946) demonstrated that elevated metabolic rates such as those observed among the Eskimos are not solely a response to low arctic temperatures (see also Rodahl 1952; LeBlanc 1957). He observed significant increases in the rate of heat production with the administration of high-protein diets over a considerable range of air temperatures, and irrespective of the type or amount of clothing worn by the subjects in his experiments.

Similarly, two arctic explorers, V. Stefansson and K. Andersen, in a study conducted in the temperate environs of New York, subsisted for an entire year on an all-meat diet. With an intake of lean meat (ca. 3\% fat), the increase in their metabolic rate varied from 14.6 to $25.0 \%$ above basal levels. In one test the increase was $45.3 \%$. On a diet in which fat provided about $75 \%$ of their calories, the increased heat production ranged from 8.6 to 22.3\% (McClellan et al. 1931; McClellan and DuBois 1930). It may be concluded from these data that heavy or complete reliance on fat-depleted meat would have elevated the total energy needed to support a group of hunters at a time of year when total caloric intake was very likely to have been restricted.

If we examine the caloric requirements of body maintenance, i.e., the calories needed for basal metabolic functions, ingestion of food, and protein balance, the impact of a high-protein diet on basic caloric needs becomes evident. Table 1 provides two different estimates of basal metabolic rates for an adult male weighing $53 \mathrm{~kg}$ and an adult female weighing $46 \mathrm{~kg}$. These weights, based on FAO/WHO developing country standards (1973:82), are below the standard weights for industrialized countries and are assumed to be representative of hunter-gatherer body weights. The estimates of basal metabolic rate do not include energy expended for metabolic processing of food (SDA), and thus an additional energy increment amounting to about $20 \%$ of the basal rate, a median figure based on the ranges of SDA values given above, must be added to estimate caloric requirements under conditions of high protein intake. Thus, as the "Total" column in Table 1 indicates, under a high-protein diet, simply to maintain the calories necessary for basal metabolism and the metabolic 
TABLE 1

Basic Caloric Requirements under a High-Protein Diet

\begin{tabular}{lccccc}
\hline Sex & $\begin{array}{c}\text { Weight } \\
(\mathrm{kg})\end{array}$ & $\begin{array}{c}\mathrm{BMR}^{a} \\
(\mathrm{kcal})\end{array}$ & $\begin{array}{c}\mathrm{SDA}^{b} \\
(\mathrm{kcal})\end{array}$ & $\begin{array}{c}\text { Total } \\
(\mathrm{kcal})\end{array}$ & $\begin{array}{c}\text { Source } \\
(\mathrm{BMR})\end{array}$ \\
\hline Male & 53 & 1600 & 320 & 1920 & $\begin{array}{c}\text { Payne } \\
(1972: 303)\end{array}$ \\
Male & 53 & 1525 & 305 & 1830 & $\begin{array}{c}\text { FAO/WHO } \\
(1973: 108)\end{array}$ \\
Female & 46 & 1350 & 270 & 1620 & $\begin{array}{c}\text { Payne } \\
(1972: 303)\end{array}$ \\
Female & 46 & 1338 & 268 & 1606 & $\begin{array}{c}\text { FAO/WHO } \\
(1973: 108)\end{array}$ \\
\hline
\end{tabular}

${ }^{a}$ Basal metabolic rate.

${ }^{b}$ Specific dynamic action (20\%).

processing of food, an adult male requires about $1800-1900 \mathrm{kcal} / \mathrm{day}$, and an adult female about $1600 \mathrm{kcal} /$ day. In comparison to a more balanced diet, whose SDA would be between about 6 and $10 \%$ rather than $20 \%$ (Briggs and Calloway 1979:32; Guthrie 1975:95), a diet composed almost entirely of lean meat requires at least $9 \%$ more calories to satisfy the same basic metabolic and physiological functions. As the above studies indicate, SDA values approaching $30 \%$ are not uncommon on all-meat diets, and at these levels at least $18 \%$ more calories are required to meet basic metabolic needs.

We can translate these caloric requirements into estimated per capita daily quantities of lean meat consumed. However, to do this we must first provide quantitative estimates of the percentage fat content of meat from wild animals, and particularly of meat from animals at the low point of their annual cycle of condition. In the present discussion we will concern ourselves entirely with large ungulates such as deer, antelope, caribou, and bison. These and other large mammals were principal targets of hunter-gatherer procurement activities. The importance of specific smaller animals during the winter and spring will be considered later.

Standard food composition tables, such as Watt and Merrill (1963), are of limited utility in this endeavor. First, very few wild ungulates have been investigated by food scientists, because these animals play an insignificant nutritional role in the modern world. Values for the amount of fat in meat of cattle, sheep, and other domestic species are far more numerous in the literature, but these figures are inappropriate in the present context since domestic animals have undergone centuries or millennia of selective breeding in favor of high levels of fat. In addition, domestic animals are often fed supplemental rations during seasons of low natural 
forage availability, and many are fattened on high-protein or high-energy "finishing" rations just prior to slaughter.

For the relatively small number of wild ungulates that have been analyzed, often only a single value is reported, and seldom is there any indication given as to whether this value represents a specific muscle or meat cut, or a composite of several cuts (e.g., "venison" of deer). These studies also rarely indicate the sex of the animals analyzed, nor do they report the reproductive status of the animals at the time of slaughter (i.e., whether pre- or post-rut in males; whether pregnant, lactating, or barren in females). Furthermore, most published values are derived from animals that presumably were slaughtered while in peak condition, whereas in the present context we are most concerned with animals at their annual low point in condition.

It should be pointed out, however, that the few minimum values that do exist for wild ungulate meat may nevertheless tend to underestimate somewhat the actual amount of fat available to hunter-gatherers in a carcass, because the values do not include subcutaneous and visceral fat deposits, fat in the bone marrow, and so forth. On the other hand, as will be discussed more fully below, many of these fat reserves may become largely or totally depleted during the winter and spring, bringing the available fat levels more in line with the values for meat alone.

In contrast to the nutrition literature, studies in wildlife biology have been very much concerned with the fat levels of wild ungulates. The amount of fat in the carcass of an animal, such as a deer or antelope, provides a very useful indicator of its overall condition, and therefore plays a critical role in management practices (cf. Harris 1945; Riney 1955). Wildlife specialists have devised a scrics of expedient indices (e.g., kidney fat index, thickness of backfat, girth measurements) which permit them to estimate condition in the field without having to resort to far more costly and time-consuming quantitative laboratory determinations of actual fat content (cf. Riney 1955). Unfortunately, these indices are very difficult to translate into data comparable to the percentage fat values of meat provided by nutritionists.

In a few cases total carcass fat has also been determined, either by densitometric techniques or by analyzing samples from homogenized carcasses. These whole-body estimates provide a reasonably accurate measure of the total amount of fat in the carcass. However, the whole-body figures overestimate the amount of fat generally available to hunter-gatherers by including lipids, such as bone grease, that are very costly in terms of time and labor for hunters to extract from the carcass.

An additional problem arises in using data from the wildlife literature. To obtain large sample sizes, data collected over several months, or even over several years, are frequently pooled. The resulting averages tend to 
obscure the impact of below-average years on the condition of the animals; and it is the minimum fat levels that are most critical to the subsistence behavior of hunters and gatherers.

Table 2 provides comparative data on the fat levels of several large wild ungulates that are known to have been of importance to hunters and gatherers in various parts of the world. Entries are included only when data are available in the form of percentage fat content. This unfortunately eliminates the bulk of observations on wildlife in which overall animal condition is assessed only by means of fat indices. It should also be noted that techniques for extracting fat have improved over the years; as a consequence, some of the values from the earlier studies listed in the table may tend to underestimate actual fat levels.

Despite the obvious shortcomings of the data presented in Table 2, they do indicate that "minimum" fat levels in the meat of many wild ungulates may reach extremely low values in the winter and spring (or in the late dry season and early rainy season in arid tropical areas). Most values are probably less than $2 \%$, and it may not be uncommon for levels to drop below $1 \%$. Moreover, many of the principal fat deposits in an animal may disappear completely, and others may be largely depleted (Harris 1945; Riney 1955; Ransom 1965; Sinclair and Duncan 1972; Pond 1978). For example, Anderson (1981:74) notes that in Colorado mule deer, "subcutaneous fat was entirely lacking in mature males and near minimal in mature females during winter." Harris (1945) made similar observations in a study of both white-tailed and mule deer in the Black Hills of South Dakota. In many of the deer he examined, the subcutaneous fat had been totally depleted by mid-February and by the end of the month fat deposits in the body cavity, including fat around the intestines, kidneys and heart, also had been completely mobilized. Dauphine (1976) observed that $100 \%$ of the backfat in the average adult barren-ground caribou had been depleted by spring, and that $70 \%$ of the abdominal fat had been mobilized. In adult Scottish red deer stags, rump fat disappeared entirely, and in females was reduced to negligible levels (Mitchell et al. 1976). Trout and Thiessen (1968) reported that $80 \%$ of the mule deer collected in late winter and spring in southwestern Idaho were in poor condition. They described this condition class as having no subcutaneous fat, less than $10 \%$ of the intestines covered by mesentary fat, and kidney fat totally depleted or present only in small patches. Stockle et al. (1978) observed zero percent fat levels during the spring around the kidneys and heart in $15-18 \%$ of male white-tailed deer and in approximately $10 \%$ of female white-tailed deer collected from various localities in the southeastern United States. Adult male elk in Michigan had little or no visceral fat following the rut (Moran 1973).

Significant reduction of fat levels in bone marrow has also been re- 


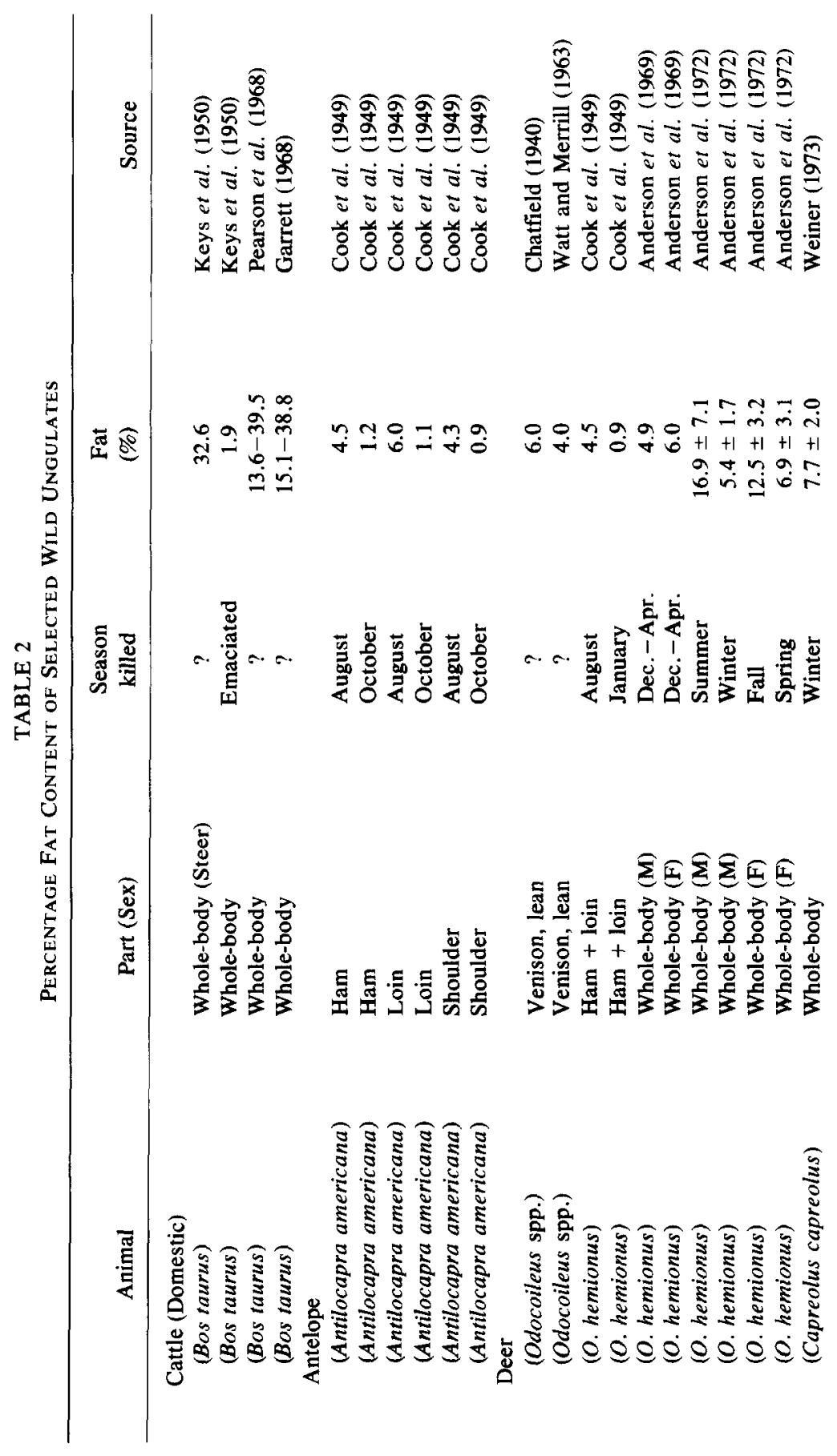




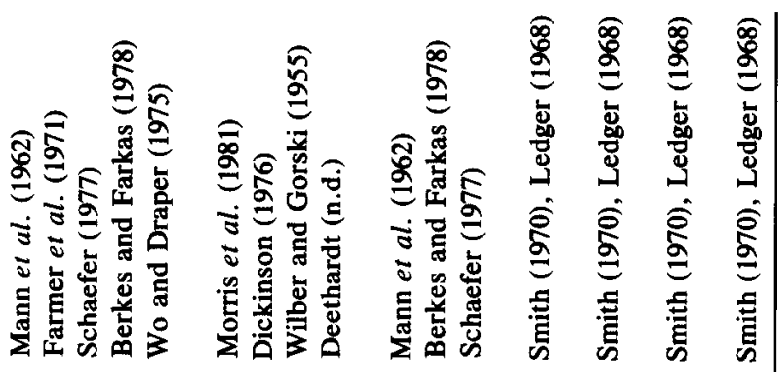

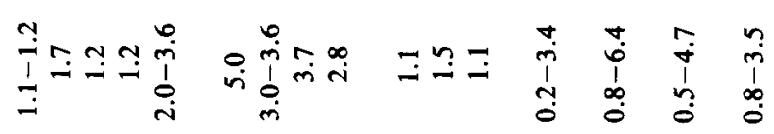

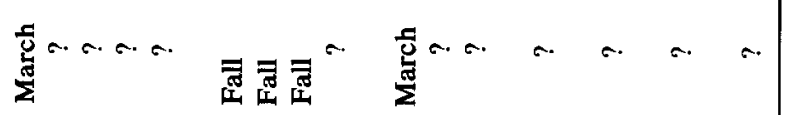

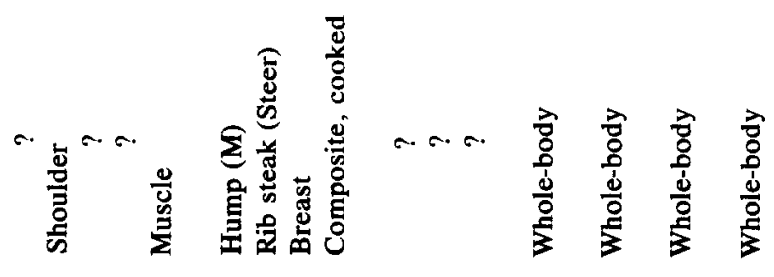

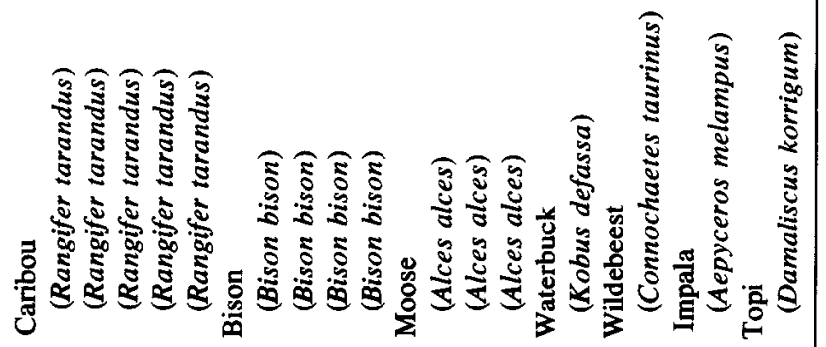


ported in many ungulates. Anderson et al. (1972), for example, observed mean spring-season fat levels of $31.9 \% \pm 28.0$ in male mule deer femora. Values of less than $20 \%$ were reported by Ratcliffe (1980) in the femora and humeri of a small sample of roe deer. Comparably low fat levels were noted by Stockle et al. (1978) in southeastern white-tailed deer femora during the spring. Alabama white-tailed deer femora from animals visually assessed to be in poor condition had a mean fat content of $27.09 \% \pm 7.32$ (Baker and Lueth 1967). Greer (1968) reported fat levels of less than $0.25 \%$ in femora of winter-killed elk. He also observed values of less than $1 \%$ in live elk collected during the spring. Franzmann and Arneson (1976) recorded an average fat level of $8.5 \% \pm 4.1$ in femora of winter-killed moose. Finally, although no actual figures are provided, Peterson (1977) found that bone marrow was almost totally fat-depleted in moose from Isle Royale, Michigan that had died of malnutrition during the late winter and spring.

We can now return to our original objective of determining the daily per capita quantity of lean meat that hunter-gatherers would have to consume in late winter and spring to fulfill their basic caloric requirements. Based on the discussion above, the meat of wild ungulates at the low point in their annual cycle of condition probably ranged in fat content from as low as $0.9 \%$ to a maximum of about $1.5-2.0 \%$. Although the major fat deposits most readily accessible to hunter-gatherers (i.e., subcutaneous and visceral fat) may be largely if not entirely depleted at this time of year, there may be smaller amounts of fat remaining in places such as the bone marrow which, while labor-intensive to extract, will augment the total fat intake. Thus, we will assume that the average amount of fat available to the hunters ranges between about 2 and $3 \%$. The protein content of meat is relatively constant at about $21 \%$ (cf. Watt and Merrill 1963).

Table 3 provides estimates of the number of kilograms of meat necessary to meet the basic daily caloric requirements for adult males and females that were presented in Table 1 . Given a diet composed entirely of lean meat ( $2-3 \%$ fat), a male would have to consume between 1.7 and 1.9 $\mathrm{kg}(3.7-4.2 \mathrm{lb}$.) of meat per day, and a female between 1.5 and $1.6 \mathrm{~kg}$ $(3.3-3.5 \mathrm{lb}$.) simply to satisfy basic metabolic needs.

These estimates do not include calories for any form of physical activity. Inclusion of calories to cover physical activity will substantially raise this need, especially since hunting requires high energy expenditure (Shephard 1974:284). For example, both summer and winter caribou hunting among traditional Canadian Eskimos require approximately 3600 kcal per 24-hour period (Shephard 1978:51). To meet these energy needs, a hunter would have to consume between 3.4 and $3.6 \mathrm{~kg}(7.5-7.9 \mathrm{lb}$.) of lean meat per day. It is important to keep in mind that the increase in hunter-gatherer caloric requirements just outlined is occurring during a 
TABLE 3

Daily Lean-Meat Requirements under a High-Protein Diet

\begin{tabular}{lccc}
\hline Sex & $\begin{array}{c}\text { Basic caloric } \\
\text { requirement } \\
(\mathrm{kcal} / \text { day })\end{array}$ & $\begin{array}{c}\text { Lean meat } \\
(2 \% \text { fat }) \\
(\mathrm{kg} / \text { day })\end{array}$ & $\begin{array}{c}\text { Lean meat }^{a} \\
(3 \% \text { fat }) \\
(\mathrm{kg} / \text { day })\end{array}$ \\
\hline Male & $\begin{array}{c}1830-1920 \\
\text { Female }\end{array}$ & $\begin{array}{c}1.8-1.9 \\
1.6\end{array}$ & $\begin{array}{c}1.7-1.8 \\
1.5\end{array}$ \\
\hline
\end{tabular}

a Adipose tissue (fat and moisture), $7.5 \mathrm{kcal} / \mathrm{g}$; protein, $4 \mathrm{kcal} / \mathrm{g}$ (McLaren 1981:32, Rodahl and Issekutz 1965:8).

season in which ungulate body weight has declined, and hence the take per animal is reduced. Moreover, herds in the spring may be widely dispersed or highly mobile in response to reduced forage availability. Thus, locating subsistence resources may become particularly difficult at this time of year and require much greater amounts of strenuous activity.

Finally, there is evidence that appetite may be depressed sharply when the protein content of the diet is high (cf. Mayer 1980:565, 575; Krauss and Mayer 1963, 1965; Henry et al. 1953). This would exacerbate the problems for hunter-gatherers of meeting their caloric needs on a diet of lean meat.

To summarize, late winter and spring would have been seasons in which hunter-gatherers may have had to rely largely on lean meat to satisfy their energy needs. Such reliance would have substantially raised their caloric requirements during a period of time when subsistence resource availability was at its lowest ebb.

\section{Protein-Sparing Action of Fat and Carbohydrate}

A second aspect of protein metabolism of interest to us here is the protein-sparing effect of nonprotein dietary energy. Protein-sparing is an important nutritional consideration when ingested protein is being utilized for providing energy. Since the body's energy needs must be fulfilled before protein needs can be met, under conditions of marginal or inadequate caloric intake, the amino acids of ingested protein are degraded, and the nonnitrogenous residues are converted to glucose or fat or are oxidized directly to meet the body's energy needs. This utilization of amino acids for energy makes protein unavailable to the body for its normal uses, and thus body protein is not replenished. Under conditions of severe caloric shortage, skeletal muscle protein will also be broken down to provide glucose for organs that do not use fat for energy.

Both fat and carbohydrate exert a protein- or nitrogen-sparing action on 
protein metabolism (Munro 1964; Richardson et al. 1979; Gelfand et al. 1979; Peret and Jacquot 1972; Goodhart and Shils 1980:820, 1128; Sim et al. 1979). This means that when either source of energy is increased, the loss of body protein is reduced. Numerous studies have demonstrated, however, that under conditions of marginal calorie, protein, or glucose intake the protein-sparing effect of carbohydrate is much greater than that of fat (Allison 1951; Allison et al. 1946; Calloway 1975; Calloway and Spector 1954; Gelfand et al. 1979; Miller 1973; Munro 1964, 1978; Nettleton and Hegsted 1975, 1977; Richardson et al. 1979; Rosenthal and Allison 1951; Torún and Young 1981; Young and Bier 1981; see also McClellan et al. 1930; Rodahl and Issekutz 1965).

It has long been known that if fat and carbohydrate are given in isocaloric amounts they do not exert an equal protein-sparing effect, and that carbohydrate is more effective than fat in promoting the utilization of dietary protein. (Richardson $e t$ al. 1979:2224)

Protein metabolism is often studied indirectly by montroring the amounts of nitrogen ingested and excreted (Guthrie 1975:64-66). If the amount of nitrogen lost is lower than the amount taken in, the individual is in positive nitrogen balance; i.e., protein is being gained. Similarly, if the amount excreted exceeds the amount ingested, the individual is in negative nitrogen balance; i.e., protein is being lost. One indication of the greater protein-sparing effect of carbohydrate is that when it is administered to fasting subjects there is a noticeable decline in the amount of nitrogen excreted. No improvement in nitrogen balance is obtained when fat is given to fasting individuals. Another indication is that when fat is substituted for carbohydrate, while holding total dietary protein and energy intake constant and at marginal to inadequate levels, nitrogen losses increase sharply.

One important reason for the greater protein-sparing effect of carbohydrate as compared to fat is that certain organs, particularly the brain and nervous system, require glucose as an energy source. If only fat and protein comprise the diet, this glucose must be derived largely from the degradation of protein, leading to higher nitrogen losses from such a diet.

Munro (1964) suggested that increased nitrogen output, resulting from substitution of fat for carbohydrate, was a transient phenomenon lasting at most about 15 days. More recent studies by Richardson et al. (1979), however, indicate that the negative nitrogen balance produced by fat substitution may persist for longer periods and may have a much more detrimental impact. They observed that

on average, the net protein utilization ... could be raised by about $13 \%$ when the diet provided the majority of the energy from carbohydrate. (Richardson et al. 1979:2223) 
Of particular interest, Richardson et al. (1979:2223) noted a considerably greater protein-sparing effect (values approaching $50 \%$ ) in individuals whose caloric intake was marginal and who were losing weight.

It is important to note that virtually all of the experimental studies to date concerning the protein-sparing action of fat and carbohydrate have involved considerably smaller total protein intakes than those with which we have been concerned in the present discussion. Thus, the magnitude of the difference in protein-sparing capacity of the two nutrients remains somewhat speculative in situations where marginal to inadequate caloric intakes consist almost entirely of protein. Given the experimental data we do have, however, it is clear that when both total calories and protein are in short supply, such as might occur seasonally in many nonarctic habitats, the relative protein-sparing efficiencies of fat and carbohydrate will be nutritionally significant. Under these conditions, carbohydrate resources should be preferentially sought over fat resources.

\section{ESSENTIAL FATTY ACID DEFICIENCY}

Another potentially serious problem faced by hunters and gatherers is a deficiency of essential fatty acids (EFA), particularly linoleic acid (Holman 1968; Mead 1980; Alfin-Slater and Aftergood 1980). Symptoms of EFA deficiency are rarely expressed in adults, because of the large reserves of essential fatty acids in their body fat. In rapidly growing infants, however, an inadequate EFA intake may be far more serious, especially in situations where the mother is malnourished and the infant is weaned to a low-fat diet (Holman 1968; Mead 1980). Major consequences of EFA deficiency include severe skin lesions, impaired water balance, reduced growth, and greater susceptibility to infection. The deleterious effects of EFA deficiency are exacerbated if caloric shortages are ameliorated with low-fat, high-protein supplements, such as skim milk, that promote growth (Mead 1980:226).

Essential fatty acid deficiencies may have posed a serious nutritional problem for hunters and gatherers during late winter and spring, if caloric intake declined to marginal or inadequate levels, stored plant foods were used up, and lean meat became the principal source of energy in the diet. Meat is a relatively poor source of linoleic acid. Plant foods such as corn and various oil-rich seeds contain much higher proportions of this critical fatty acid (Mead 1980).

Minimum requirements for linoleic acid in humans are somewhat controversial. In adults the level is commonly placed at approximately $2 \%$ of total calories, or about $7.5 \mathrm{~g}$ for an adult male on a daily caloric budget of $3000 \mathrm{kcal}$ (Alfin-Slater and Aftergood 1980:135; McLaren 1981:95). The 


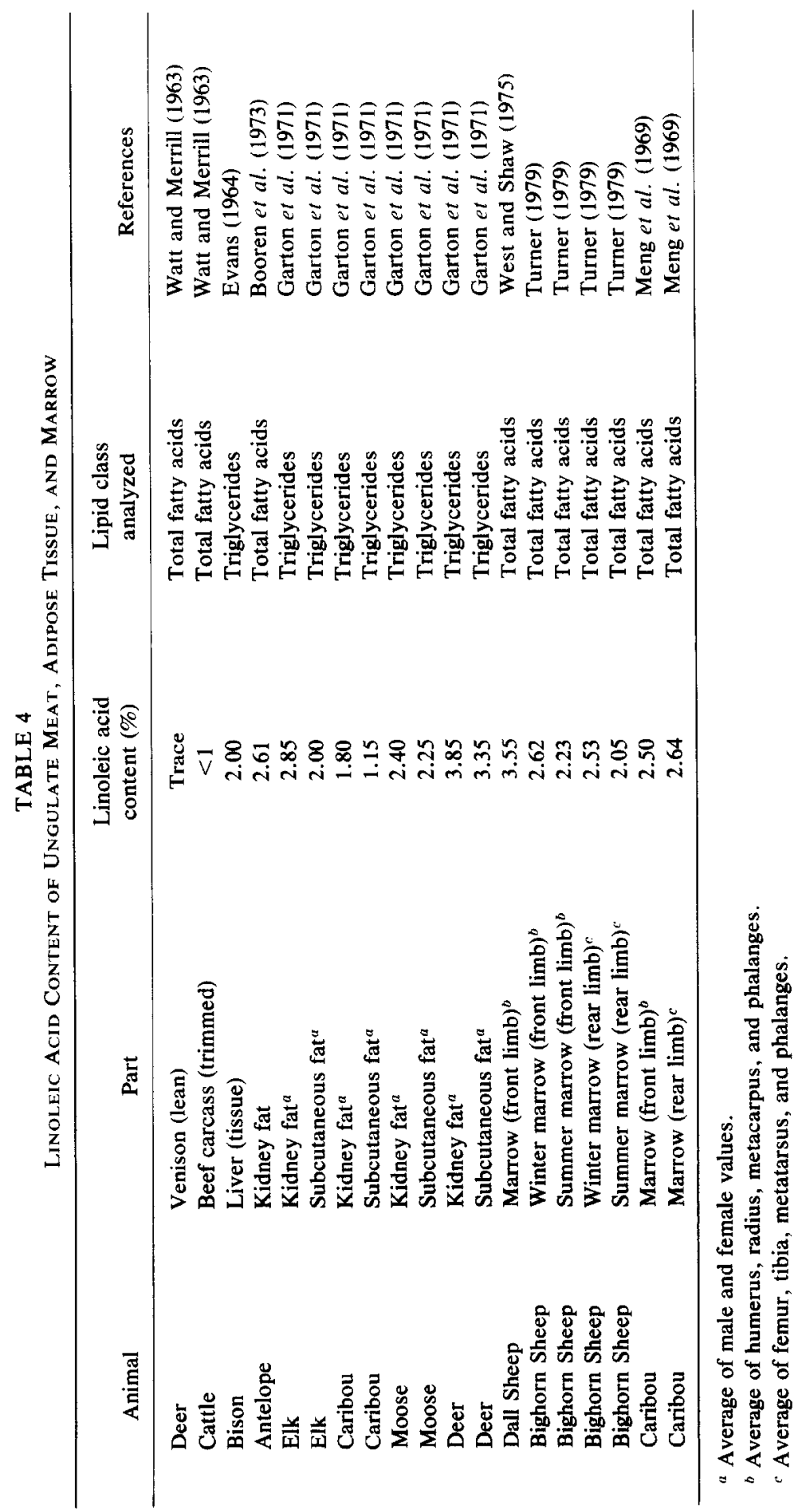


minimum daily requirement for infants is about $0.5 \%$ of calories (Cuthbertson 1976:559).

Available data concerning the linoleic acid content of various tissues in wild and domestic ungulates are presented in Table 4. Most of these data reflect the fatty acid composition of adipose tissue. Values tend to fall between 2 and 3\%. Very few figures are available for the linoleic acid content of lean meat, the portion of the carcass of most concern to us in the present discussion. The data presented by Watt and Merrill (1963) for venison and various cuts of beef suggest that linoleic acid values in lean meat generally fall below $2 \%$ and often well below $1 \%$ (i.e., "trace"). It should also be pointed out that all of the figures in Table 4 are derived from animals in peak condition. It is clear, however, that linoleic acid levels vary with season, attaining maximum values in late fall and winter and minimum values in late spring and summer (Turner 1979; Link et al. 1970). Thus, typical levels of linoleic acid in lean meat available to hunter-gatherers in late winter and spring probably rarely exceeded $2 \%$.

Table 5 summarizes the amount (and percentage of total calories) of linoleic acid in lean meat, using an EFA value of $2 \%$ and a total fat content of $2 \%$. It is clear from these data that linoleic acid intakes would seldom have reached $1 \mathrm{~g}$, or only about $0.3 \%$ of total calories. These values are well below the minimum recommended levels for infants and adults.

While these low values do not necessarily imply linoleic acid deficiency in adults, they do suggest that a more susceptible cohort, the infants, may be experiencing severe stress. With lower fat reserves to draw upon than adults, infants should be affected more severely by short-term, seasonal linoleic acid deficiencies. We expect that, owing to the greater susceptibility to infection that accompanies a deficiency in linoleic acid, infant mortality may rise in hunter-gatherer populations that rely seasonally on lean-meat diets.

Lack of fat in the human diet has effects other than reduction in essential fatty acid intake. For example, adequate fat is important in calcium

TABLE 5

Linoleic Acid Levels in Hunter-Gatherer Diet

\begin{tabular}{ccccc}
\hline $\begin{array}{c}\text { Lean meat } \\
(\mathrm{kg})\end{array}$ & $\begin{array}{c}\text { Total }^{a} \\
\text { calories } \\
(2 \% \text { fat })\end{array}$ & $\begin{array}{c}\text { Amount } \\
(\mathrm{kcal})\end{array}$ & $\begin{array}{c}\text { Calories } \\
(\mathrm{kcal})\end{array}$ & $\begin{array}{c}\text { Percentage of } \\
\text { total calories }\end{array}$ \\
\hline 1.5 & 1530 & 0.6 & 5.4 & 0.35 \\
2.5 & 2550 & 1.0 & 9.0 & 0.35 \\
3.5 & 3570 & 1.4 & 12.6 & 0.35 \\
\hline
\end{tabular}

a Fat, $9 \mathrm{kcal} / \mathrm{g}$; protein, $4 \mathrm{kcal} / \mathrm{g}$. 
absorption (Alfin-Slater and Aftergood 1980:120-121) and as a source of fat-soluble vitamins (Morton 1970). In addition, high protcin intake tends to inhibit calcium absorption (Linkswiler 1976:234-236) and may lead to imbalances in the body's acid-base levels (Briggs and Calloway 1979:368; Goldberger 1975). Though we lack quantitative data concerning the consequences of seasonal restrictions in fat intake on these metabolic processes, the existence of deficiencies other than those on which we have focused our discussion should be noted.

\section{HUNTER-GATHERER FORAGING STRATEGIES}

The above observations concerning the specific dynamic action of protein ingestion, the protein-sparing effect of dietary carbohydrate, and essential fatty acid deficiencies resulting from lean-meat diets have important implications for understanding certain critical aspects of hunter-gatherer subsistence behavior. Let us assume in the following discussion that we are dealing with hunting and gathering populations in temperate grassland, subarctic, or inland arctic environments during the late winter and spring. As mentioned above, this is the most stressful period of the year, one often characterized by diminishing stored food supplies, the scarcity or absence of collectible plant foods, and a decline in total per capita calorie intake.

To compensate for declining total energy levels and dwindling food reserves, hunter-gatherers in these environments may be forced to increase their emphasis on hunting large ungulate species such as deer, elk, moose, caribou, and bison. Since these animals are also subsisting on diets of declining nutritional worth, their body-fat reserves are becoming depleted and the hunters will be taking in increasing proportions of lean meat.

It is clear from the above discussion, however, that because of the high specific dynamic action of protein and the low levels of linoleic acid, lean-meat diets provide an inefficient and often inadequate source of sustenance for hunters and gatherers at times when their intake of carbohydrate and total energy is restricted. As a consequence, in anticipation of recurrent (e.g., seasonal) periods when caloric needs cannot be met by lean meat consumption, it is expected that hunters and gatherers will concentrate on subsistence strategies that increase the availability of carbohydrate and/or fat at the critical time of year. Three types of strategies would achieve this result:

(1) increasingly selective procurement and processing of animals with high fat content, 
(2) storage of fat- and carbohydrate-rich foods,

(3) exchange for fat- or carbohydrate-rich foods.

During seasons of potential caloric deficiency, hunter-gatherers may become much more selective in procuring fat animals and in processing fat-rich body parts (cf. Speth 1983). When possible, hunter-gatherers may shift their hunting emphasis from potentially fat-depleted ungulates to animal species that normally maintain higher levels of body fat in winter and spring. These include bear, beaver, certain species of fish, various migratory waterfowl, and others, depending of course on habitat and abundance (cf. Rogers 1972; see Aleksiuk and Cowan 1969a, 1969b for data on seasonal fat-level fluctuations in beaver).

The second strategy, storage of fat or carbohydrate, has two components. First, humans can accumulate reserves of body fat. As Munro (1964:431) and Peret and Jacquot (1972:90) point out, an excess of body fat is a protection against wastage of body proteins during severe dietary restriction. An ethnographic example of this practice, though not pertaining to meat consumption per se, is the late-summer gorging on pitahaya (organ-pipe cactus) fruits by hunter-gatherers in Baja California, who, as a consequence, became quite corpulent (J. Baegert, cited in Castetter and Bell 1937:31; see also Lee 1979:272). The practice of accumulating body fat reserves in times of plenty to supply energy in times of nutritional stress also may help account for the seemingly anomalous gorging on meat at bison kills frequently noted by early North American travelers and explorers (see discussion in Wheat 1972:108-109).

Second, hunter-gatherers may augment their supplies of storable fat through labor-intensive activities such as rendering bone grease. Preparation of bone grease involves smashing the bone, heavy limb elements as well as lighter vertebrae and ribs, and then boiling the small pieces of bone in water until the grease is extracted. Grease is skimmed off the water and placed in skin containers to harden. Among nomadic groups lacking pottery, the laborious boiling process is accomplished by heating rocks in a fire and transferring them to a perishable container such as a skin bag that contains the broken-up bones (see Binford 1978 for a description of grease rendering). Commonly, the rendered fat is mixed with an equal proportion of pulverized, jerked lean meat to make pemmican, an energyrich food that can be stored for several years if kept dry (Stefansson 1956:179, 188).

The degree of mobility and the transport capabilities of the population, however, may place severe constraints on the amount of fat that can be stored. Problems of this nature probably obtained, for example, for many prehistoric Plains hunter-gatherer populations who wintered off the 
Plains, but whose transportation facilities (dogs and humans) limited the quantities of fat, or fat plus meat (pemmican), that could be transported from kills made on the Plains.

In light of the greater protein-sparing capacity of carbohydrate compared to fat, and the higher essential fatty acid content of many plant foods, hunter-gatherers, when possible, may place equal or greater emphasis on building up storable carbohydrate reserves during the fall than on hunting, particularly in areas where adequate supplies of fat cannot be reliably produced (see, for example, the discussion in Lee 1968). Thus, we propose that higher quantities of carbohydrate will be included in hunter-gatherer diets than would be expected given the relative availability of carbohydrate and protein in these environments.

Where neither fat surpluses nor carbohydrate-rich wild plant foods are available in adequate quantities to store for winter use, hunter-gatherers may supplement their carbohydrate/fat reserves by consuming insects (including fly larvae in spring caribou hides), seaweed, the entrails of ptarmigans and the stomach contents of caribou, bark, and a variety of other foods (cf. Eidlitz 1969; Nickerson et al. 1973).

Trade for fat or carbohydrate with other populations provides another widely practiced alternative. For example, Nunamiut Eskimos who relied heavily on caribou for subsistence annually traded for fat and seaweed with coastal-dwelling Taremiut (Gubser 1965; Spencer 1959; Eidlitz 1969:50). The same situation obtained for inland Athabascan groups who traded skins, blankets, and tools to Eskimo and Northwest Coast populations in return for seal, whale, or oulachen oil (Olson 1936; Birket-Smith and de Laguna 1938; People of 'Ksan 1980:89ff.; Kuhnlein et al. 1982).

Where storage is not feasible due to group mobility, hunter-gatherers may rely on the storage capacities of horticultural populations and make seasonal trips to horticultural villages to trade for carbohydrate resources. Hunter-gatherer exchange of meat with horticultural populations in return for carbohydrates is documented for many areas of the world (e.g., Peterson 1978; Turnbull 1965; Hammond and Rey 1953; Ewers 1954; cf. Spielmann 1982). In temperate climates such exchange coincided with seasons during which hunter-gatherers were experiencing reduction in available food resources and probably nutritional stress.

Limited cultivation by hunter-gatherers has also been documented (e.g., Peterson 1978; Thomas 1935). Such cultivation is often sporadic and does not approach the efficiency of full-time horticulturists. Little research has been conducted concerning the significance of these limited amounts of cultivated carbohydrates in the hunter-gatherer diet. The argument presented here would suggest that this desultory cultivation is a buffering strategy which provides a backup source of carbohydrate during 
seasons in which lean meat becomes an increasingly large proportion of the diet.

\section{CONCLUSIONS}

In this paper we have focused on alternative strategies open to hunter-gatherers to cope with nutritional deficiencies which occur seasonally in environments where ungulate meat forms the principal available resource in late winter and spring. In environments where alternative, fattier species such as beaver, raccoon, or migratory waterfowl are normally available in the spring, heavy reliance on lean ungulate meat and its associated nutritional problems might nevertheless occur periodically during "bad" years in which the number of smaller game animals is significantly depressed. It is also possible that such reliance may occur chronically in areas of the subarctic where caribou constitute the primary, year-round subsistence resource (cf. Burch 1972). Thus, while the emphasis of our discussion has been on the consequences of recurrent, winter-spring reliance on ungulate meat, the susceptibility of populations to the deficiencies discussed above actually ranges over a continuum from periodic to seasonal to chronic, depending on the frequency with which lean ungulate meat constitutes a major part of the hunter-gatherer diet.

In addition, these same arguments may be extended to situations in which climatic, environmental, demographic, or other changes lead to long-term reductions in available energy. Under such conditions, selection may favor a permanent shift in the subsistence strategies of hunters and gatherers toward greater emphasis on carbohydrate resources. The apparent increase in reliance on plant foods in many parts of the world following the end of the Pleistocene might profitably be explored from this perspective. The greater protein-sparing capacity of carbohydrate under conditions of marginal calorie or protein intake may also help to explain why hunter-gatherers in the early Holocene began to invest time and energy cultivating plants, despite the meager returns many of these cultigens would have provided in their early stages of domestication. Similarly, a long-term increase in the availability of carbohydrates, due, for example, to the introduction of a cultivated plant species, may alter the importance to hunter-gatherers of animal fat, and may lead to permanent changes in the animal species they procure, the parts they select during butchering and processing, the importance of marrow production and grease rendering, and the season of the year they hunt or trap. The inadequacies of a lean-meat diet and the noninterchangeability of fat and carbohydrate clearly open a number of interesting avenues of research that remain to be explored in detail. 


\section{ACKNOWLEDGMENTS}

This paper developed from research that was partially funded by grants from the National Science Foundation (BNS 78-06875, BNS 80-11489), the Wenner-Gren Foundation for Anthropological Research, and the American Association of University Women. We gratefully acknowledge the support of these agencies.

We are extremely grateful to Stanley M. Garn and Alfred E. Harper for their valuable suggestions and insightful criticisms of the manuscript. We acknowledge the help of C. Loring Brace, Jane E. Buikstra, Richard I. Ford, Gregory A. Johnson, Arthur S. Keene, Harriet V. Kuhnlein, Thomas L. Leatherman, and an anonymous reviewer. We of course assume full responsibility for whatever errors and shortcomings remain in the final version.

\section{REFERENCES CITED}

Aleksiuk, M., and I. M. Cowan

1969a Aspects of seasonal energy expenditure in the beaver (Castor canadensis Kuhl) at the northern limit of its distribution. Canadian Iournal of Zoology 47:471-481.

1969b The winter metabolic depression in arctic beavers (Castor canadensis Kuhl) with comparisons to California beavers. Canadian Journal of Zoology 47:965-979.

Alfin-Slater, R. B., and L. Aftergood

1980 Lipids. In Modern nutrition in health and disease (sixth ed.), edited by R. S. Goodhart and M. E. Shils, pp. 113-141. Lea \& Febiger, Philadelphia.

Allen, Durward L.

1979 Wolves of Minong. Houghton Mifflin, Boston.

Allison, James B.

1951 Interpretation of nitrogen balance data. Federation Proceedings 10:676-683.

Allison, J. B., J. A. Anderson, and R. D. Seeley

1946 The determination of the nitrogen balance index in normal and hypoproteinemic dogs. New York Academy of Sciences Annals 47:245-271.

Anastasio, Angelo

1972 The southern plateau: An ecological analysis of intergroup relations. Northwest Anthropological Research Notes 6:109-229.

Anderson, Allen E.

1981 Morphological and physiological characteristics. In Mule and black-tailed deer of North America, edited by O. C. Wallmo, pp. 27-98. Univ. of Nebraska Press, Lincoln.

Anderson, A. E., D. E. Medin, and D. C. Bowden

1972 Indices of carcass fat in a Colorado mule deer population. Journal of Wildlife Management 36:579-594.

Anderson, A. E., D. E. Medin, and D. P. Ochs

1969 Relationships of carcass fat indices in 18 wintering mule deer. Western Association of State Game and Fish Commissioners, Western Proceedings 49:329-340.

Baker, M. F., and F. X. Lueth

1967 Mandibular cavity tissue as a possible indicator of condition in deer. Southeastern Association of Game and Fish Commissioners, Conference Proceedings 20:69-74. 
Balikci, Asen

1968 The Netsilik Eskimos: adaptive processes. In Man the hunter, edited by R. B. Lee and I. DeVore, pp. 78-82. Aldine, Chicago.

Barnes, Richard H.

1976 Energy. In Present knowledge in nutrition (fourth ed.), edited by D. M. Hegsted et al., pp. 10-16. Nutrition Foundation, New York.

Bean, Lowell J.

1972 Mukat's people: the Cahuilla Indians of Southern California. Univ. of California Press, Berkeley.

Berkes, F., and C. S. Farkas

1978 Eastern James Bay Cree Indians: Changing patterns of wild food use and nutrition. Ecology of Food and Nutrition 7:155-172.

Bigwood, E. J. (editor)

1972 Protein and amino acid functions. Pergamon Press, Oxford.

Binford, Lewis R.

1978 Nunamiut ethnoarchaeology. Academic Press, New York.

Birket-Smith, Kaj, and Frederica de Laguna

1938 The Eyak of the Copper River Delta. Copenhagen.

Booren, A., R. A. Field, and J. E. Kunsman, Jr.

1973 Carbonyl and fatty acid analysis of antelope and beef fat. Journal of Food Science 38:63-65.

Bourlière, F.

1964 The natural history of mammals (third ed., revised). Alfred A. Knopf, New York.

Briggs, G. M., and D. H. Calloway

1979 Bogert's nutrition and physical fitness (tenth ed.). W. B. Saunders, Philadelphia.

Buikstra, Jane E.

1976 The Caribou Eskimo: General and specific disease. American Journal of Physical Anthropology 45:351-368.

1981 Mortuary practices, palaeodemography and palaeopathology: A case study from the Koster site (Illinois). In The archaeology of death, edited by R. Chapman,

Burch, Ernest I. Kinnes, and K. Randsborg, pp. 123-155. Cambridge Univ. Press, London.

1972 The caribou/wild reindeer as a human resource. American Antiquity 37:339-368.

Calloway, D. H.

1975 Nitrogen balance of men with marginal intakes of protein and energy. Journal of Nutrition 105:914-923.

Calloway, D. H., and H. Spector

1954 Nitrogen balance as related to caloric and protein intake in active young men. American Journal of Clinical Nutrition 2:405-412.

Cassidy, C. M.

1972 A comparison of nutrition and health in preagricultural and agricultural Amerindian skeletal populations. Unpublished Ph.D. dissertation, Department of Anthropology, University of Wisconsin.

Castetter, E. F., and W. H. Bell

1937 Ethnobiological studies in the American Southwest, IV. The aboriginal utilization of the tall cacti in the American Southwest. University of New Mexico Bulletin 307, Biological Series 5:1-48. 
Chaney, Margaret S., and Margaret L. Ross

1971 Nutrition (eighth ed.). Houghton Mifflin, Boston.

Chatfield, Charlotte

1940 Proximate composition of American food materials. U.S. Department of Agriculture Circular 549.

Cook, B. B., L. E. Witham, M. Olmstead, and A. F. Morgan

1949 The influence of seasonal and other factors on the acceptability and food value of the meat of two subspecies of California deer and of antelope. Hilgardia 19:265-284.

Coues, Elliott (editor)

1893 The history of the Lewis and Clark Expedition (Vol. 1). Francis P. Harper, New York.

1898 The journal of Jacab Fowler. Francis P. Harper, New York.

Cox, George

1978 Famine symposium, the ecology of famine: An overview. Ecology of Food and Nutrition 6:207-220.

Cuthbertson, W. F. J.

1976 Essential fatty acid requirements in infancy. American Journal of Clinical Nutrition 29:559-568.

Dauphiné, T. C., Jr.

1976 Biology of the Kaminuriak population of barrenground caribou, Part 4. Growth,

Deethardt, Dorothy reproduction and energy reserves. Canadian Wildlife Service Report Series 38.

n.d. The best of bison. South Dakota State University, Agricultural Experiment Station B668, Brookings.

Dickinson, Charles E. (editor)

1976 Carcass characteristics of a bison steer (Bison bison). U.S./I.B.P. Grassland Biome Technical Report 302. Colorado State University, Fort Collins.

Dirks, Robert

1980 Social responses during severe food shortages and famine. Current Anthropology 21:21-44.

Draper, H. H.

1980 Nutrition. In The human biology of circumpolar populations, edited by F. A. Milan, pp. 257-284. International Biological Programme 21. Cambridge Univ. Press, Cambridge.

Eidlitz, Kerstin

1969 Food and emergency food in the circumpolar area. Studia Ethnographica Upsaliensia 32:1-175.

Evans, Laura

1964 Comparison of fatty acids from lipid classes of serum lipoproteins and other lipids in the bison. Journal of Dairy Science 47:46-53.

Ewers, J. C.

1954 The Indian trade of the Upper Missouri before Lewis and Clark. Missouri Historical Society Bulletin 10:429-446.

FAO/WHO (Food and Agriculture Organization/World Health Organization)

1973 Energy and protein requirements. United Nations FAO Nutrition Meetings, Report Series 52, Rome.

Farmer, F. A., M. L. Ho, and H. R. Neilson

1971 Analyses of meats eaten by humans or fed to dogs in the arctic. Journal of the Canadian Dietetic Association 32:137-141. 
Franzmann, A. W., and P. D. Arneson

1976 Marrow fat in Alaskan moose femurs in relation to mortality factors. Journal of Wildlife Management 40:336-339.

Garrett, W. N.

1968 Experiences in the use of body density as an estimator of body composition of animals. In Body composition in animals and man, pp. 170-185. National Academy of Sciences Publication 1598.

Garton, G. A., W. R. H. Duncan, and E. H. McEwan

1971 Composition of adipose tissue triglycerides of the elk (Cervus canadensis), caribou (Rangifer tarandus groenlandicus), moose (Alces alces), and whitetailed deer (Odocoileus virginianus). Canadian Journal of Zoology 49:1159-1162.

Gelfand, R. A., R. G. Hendler, and R. S. Sherwin

1979 Dietary carbohydrate and metabolism of ingested protein. Lancet 1:65-68.

Goldberger, Emanuel

1975 A primer of water, electrolyte and acid-base syndromes (fifth ed.). Lea \& Febiger, Philadelphia.

Goldschmidt, Walter

1951 Nomlaki ethnography. University of California Publications in American Archaeology and Ethnology 42:303-443.

Goodhart, Robert S., and Maurice E. Shils (editors)

1980 Modern nutrition in health and disease (sixth ed.). Lea \& Febiger, Philadelphia.

Greer, Kenneth R.

1968 A compression method indicates fat content of elk (wapiti) femur marrows. Journal of Wildlife Management 32:747-751.

Grinnell, George B.

1972 The Cheyenne Indians: their history and ways of life (Vol. 1). Univ, of Nebraska Press, Lincoln.

Gubser, N. J.

1965 The Nunamiut Eskimos: hunters of caribou. Yale Univ. Press, New Haven.

Gusinde, Martin

1961 The Yamana: The life and thought of the water nomads of Cape Horn, translated by Frieda Schutze, Human Relations Area Files, New Haven.

Guthrie, Helen A.

1975 Introductory nutrition, (third ed.). C. V. Mosby, St. Louis,

Hammond, George P., and Agapito Rey

1953 Don Juan de Oñate, colonizer of New Mexico. Univ. of New Mexico Press,

Harris, Dave Albuquerque.

1945 Symptoms of malnutrition in deer. Journal of Wildlife Management 9:319-322.

Hayden, Brian

1981 Subsistence and ecological adaptations of modern hunter/gatherers. In $\mathrm{Om}$ nivorous primates, edited by R. S. O. Harding and G. Teleki, pp. 344-421. Columbia Univ. Press, New York.

Henry, K. M., H. W. Kosterlitz, and M. H. Quenouille

1953 A method for determining the nutritive value of a protein by its effect on liver protein. British Journal of Nutrition 7:51-67.

Hitchcock, R. K.

1978 The traditional response to drought in Botswana. In Proceedings of the symposium on the drought in Botswana, edited by M. Hinchey, pp. 91-97. Clark Univ. Press, Worchester. 
Hodge, Frederick W.

1907 The narrative of Alvar Nunez Cabeza de Vaca. In Spanish explorers in the southern United States 1528-1543, edited by F. W. Hodge and T. H. Lewis, pp.

Holman, Ralph T. 1-126. Barnes \& Noble, New York.

1968 Essential fatty acid deficiency. Progress in the Chemistry of Fats and other Lipids 9:275-348.

Houssay, B. A., et al.

1955 Human physiology (second ed.). McGraw-Hill, New York.

Høygaard, Arne

1941 Studies on the nutrition and physio-pathology of Eskimos, undertaken at Angmagssalik, East-Greenland 1936-1937. Norske Videnskapsakademi i Oslo, Skrifter 1. Matematisk-Naturvidenskapelig Klasse 1940(9).

Huss-Ashmore, R., A. H. Goodman, and G. J. Armelagos

1982 Nutritional inference from paleopathology. In Advances in archaeological method and theory (Vol. 5), edited by M. B. Schiffer, pp. 395-474. Academic Press, New York.

Itoh, $\mathrm{S}$.

1980 Physiology of circumpolar people. In The human biology of circumpolar populations, edited by F. A. Milan, pp. 285-303. International Biological Programme 21. Cambridge Univ. Press, Cambridge.

Jenness, Diamond

1923 Report of the Canadian Arctic Expedition, 1913-1918 (Southern Party, 1913-1916) (Vol. 12). The Copper Eskimos. F. A. Acland, Ottawa.

Jochim, Michael A.

1981 Strategies for survival. Academic Press, New York.

Kelly, Isabel T.

1964 Southern Paiute ethnography. University of Utah Department of Anthropology, Anthropological Paper 69.

Keys, A., et al.

1950 The biology of human starvation (Vol. 1). Univ. of Minnesota Press, Minneapolis.

Krauss, R. M., and J. Mayer

1963 'Safety valve' effect of excess dietary amino acids and protein on food intake in hyperphagic rats. Nature (London) 200:1213-1214.

1965 Influence of protein and amino acids on food intake in the rat. American Journal of Physiology 209:479-483.

Kuhnlein, H. V., A. C. Chan, J. N. Thompson, and S. Nakai

1982 Ooligan grease: A nutritious fat used by native people of coastal British Columbia. Journal of Ethnobiology 2:154-161.

Laughlin, Charles, Jr., and Ivan Brady (editors)

1978 Extinction and survival in human populations. Columbia Univ. Press, New York.

LeBlanc, J. A.

1957 Effect of environmental temperature on energy expenditure and caloric requirements. Journal of Applied Physiology 10:281-283.

Ledger, $H$. P.

1968 Body composition as a basis for a comparative study of some East African mammals. Symposia of the Zoological Society of London 21:289-310.

Lee, Richard $\mathbf{B}$.

1968 What hunters do for a living, or, how to make out on scarce resources. In Man the hunter, edited by R. B. Lee and I. DeVore, pp. 30-48. Aldine, Chicago. 
1979 The !Kung San: Men, women, and work in a foraging society. Cambridge Univ. Press, New York.

Link, B. A., R. W. Bray, R. G. Cassens, and R. G. Kauffman

1970 Fatty acid composition of bovine subcutaneous adipose tissue lipids during growth. Journal of Animal Science 30:722-725.

Linkwsiler, H. M.

1976 Calcium. In Present knowledge in nutrition (fourth ed.), edited by D. M. Hegsted et al., pp. 232-240. Nutrition Foundation, New York.

Long, William $\mathbf{H}$.

1946 The effect of the protein level in the diet on resistance to cold with special reference to the gaseous exchange and the reaction of the body thermostat at low temperatures. U.S. Office of Scientific Research and Development, Committee on Medical Research, Washington, D.C.

McClellan, W. S., and E. F. DuBois

1930 Clinical calorimetry, XLV. Prolonged meat diets with a study of kidney function and ketosis. Journal of Biological Chemistry 87:651-668.

McClellan, W. S., V. R. Rupp, and V. Toscani

1930 Clinical calorimetry, XLVI. Prolonged meat diets with a study of the metabolism of nitrogen, calcium, and phosphorus. Journal of Biological Chemistry 87:669-680.

McClellan, W. S., H. J. Spencer, and E. A. Falk

1931 Clinical calorimetry, XLVII. Prolonged meat diets with a study of the respiratory metabolism. Journal of Biological Chemistry 93:419-434.

McHenry, Henry

1968 Transverse lines in long bones of prehistoric California Indians. American Journal of Physical Anthropology 29:1-18.

McHenry, H. M., and P. D. Schultz

1978 Harris lines, enamel hypoplasia, and subsistence change in prehistoric central California. In Selected papers from the 14th Great Basin Anthropological Conference, edited by D. R. Tuohy, pp. 35-50. Ballena Press, Socorro, N. Mex.

McLaren, Donald S.

1981 Nutrition and its disorders (third ed.). Churchill Livingstone, Edinburgh.

Mann, G. V., et al.

1962 The health and nutritional status of Alaskan Eskimos. American Journal of Clinical Nutrition 11:31-76.

Marcy, Randolph B.

1863 The prairie traveler: $A$ handbook for overland expeditions. Trubner \& Company, London.

Mayer, Jean

1980 Physiology of hunger and satiety. In Modern nutrition in health and disease (sixth ed.), edited by R. S. Goodhart and M. E. Shils, pp. 560-577. Lea \& Febiger, Philadelphia.

Mead, James F.

1980 Nutrients with special functions: Essential fatty acids. In Nutrition and the adult: Macronutrients, edited by R. B. Alfin-Slater and D. Kritchevsky, pp. 213-238. Plenum, New York.

Meng, M. S., G. C. West, and L. Irving

1969 Fatty acid composition of caribou bone marrow. Comparative Biochemistry and Physiology 30B:187-191.

Miller, D. S.

1973 Protein-energy interrelationships. In Proteins in human nutrition, edited by J. W. G. Porter and B. A. Rolls, pp. 93-101. Academic Press, London. 
Minnis, Paul E.

1981 Economic and organizational responses to food stress by non-stratified societies: An example from prehistoric New Mexico. Unpublished Ph.D. dissertation, Department of Anthropology, University of Michigan.

Mitchell, B., D. McCowan, and I. A. Nicholson

1976 Annual cycles of body weight and condition in Scottish red deer, Cervus elaphus. Journal of Zoology (London) 180:107-127.

Moran, Richard J.

1973 The Rocky Mountain elk in Michigan. Michigan Department of Natural Resources, Research and Development Report 267.

Morris, E. A., W. M. Witkind, R. L. Dix, and J. Jacobson

1981 Nutritional content of selected aboriginal foods in northeast Colorado: Buffalo (Bison bison) and wild onions (Allium spp.). Journal of Ethnobiology 1:213-220.

Morton, R. A. (editor)

1970 Fat-soluble vitamins. Pergamon Press, Oxford.

Munro, H. N.

1964 General aspects of the regulation of protein metabolism by diet and by hormones. In Mammalian protein metabolism (Vol. 1), edited by H. N. Munro and J. B. Allison, pp. 381-481. Academic Press, New York.

1978 Energy intake and nitrogen metabolism. Ross Conference on Medical Research 1:105-110. Ross Laboratories, Columbus.

Nelson, Richard K.

1973 Hunters of the northern forest: Designs for survival among the Alaskan Kutchin. Univ. of Chicago Press, Chicago.

Nettleton, J. A., and D. M. Hegsted

1975 Protein-energy interrelationships during dietary restriction: Effects on tissue nitrogen and protein turnover. Nutrition and Metabolism 18:31-40.

1977 Short- and long-term effects on nitrogen metabolism of feeding protein during mild or severe energy restriction. Journal of Nutrition 107:1909-1917.

Newman, James L.

1975 Dimensions of the Sandawe diet. Ecology of Food and Nutrition 4:33-39.

Nickerson, N. H., N. H. Rowe, and E. A. Richter

1973 Native plants in the diets of North Alaskan Eskimos. In Man and his foods, edited by C. Earle Smith, Jr., pp. 3-27. Univ. of Alabama Press, University, Alabama.

Nordan, H. C., I. McT. Cowan, and A. J. Wood

1968 Nutritional requirements and growth of black-tailed deer, Odocoileus hemionus columbianus, in captivity. Symposia of the Zoological Society of London 21:89-96.

Olson, Ronald L.

1936 Some trading customs of the Chilkat Tlingit. In Essays in anthropology presented to A. L. Kroeber, edited by R. H. Lowie, pp. 211-214. Univ. of California Press, Berkeley.

Payne, P. R.

1972 Protein quality of diets, chemical scores and amino acid imbalances. In Protein and amino acid functions, edited by E. J. Bigwood, pp. 259-306. Pergamon Press, Oxford.

Pearson, A. M., R. W. Purchas, and E. P. Reineke

1968 Theory and potential usefulness of body density as a predictor of body composition. In Body composition in animals and man, pp. 153-169. National Academy of Sciences Publication 1598. 
People of 'Ksan

1980 Gathering what the great nature provided. Douglas \& McIntyre, Vancouver.

Peret, Jean, and Raymond Jacquot

1972 Nitrogen excretion on complete fasting and on a nitrogen-free dietEndogenous nitrogen. In Protein and amino acid functions, edited by E. J. Bigwood, pp. 73-118. Pergamon Press, Oxford.

Peterson, Jean T.

1978 The ecology of social boundaries: Agta foragers of the Philippines. Illinois Studies in Anthropology 11. Univ. of Illinois Press, Urbana.

Peterson, Rolf $\mathrm{O}$.

1977 Wolf ecology and prey relationships on Isle Royale. National Park Service Scientific Monograph Series 11.

Phillips, Paul C. (editor)

1940 Life in the Rocky Mountains, by W. A. Ferris. Old West Publ. Denver.

Piddocke, Stuart

1965 The potlatch system of the Southern Kwakiutl: A new perspective. Southwestern Journal of Anthropology 21:244-264.

Pond, Caroline $\mathrm{M}$.

1978 Morphological aspects and the ecological and mechanical consequences of fat deposition in wild vertebrates. Annual Review of Ecology and Systematics 9:519-570.

Ransom, A. Brian

1965 Kidney and marrow fat as indicators of white-tailed deer condition. Journal of Wildlife Management 29:397-398.

Ratcliffe, P. R.

1980 Bone marrow fat as an indicator of condition in roe deer. Acta Theriologica $25: 333-340$.

Richardson, D. P., A. H. Wayler, N. S. Scrimshaw, and V. R. Young

1979 Quantitative effect of an isoenergetic exchange of fat for carbohydrate on dietary protein utilization in healthy young men. American Journal of Clinical Nutrition 32:2217-2226.

Riney, $\mathrm{T}$.

1955 Evaluating condition of free-ranging red deer (Cervus elaphus), with special reference to New Zealand. New Zealand Journal of Science and Technology 36:429-463.

Rodahl, Kaare

1952 Basal metabolism of the Eskimo. Journal of Nutrition 48:359-368.

Rodahl, K., and B. Issekutz, Jr.

1965 Nutritional effects on human performance in the cold. In Nutritional requirements for survival in the cold and at altitude, edited by Lucile Vaughan, pp. 7-47. Symposia on Arctic Biology and Medicine Proceedings 5. Arctic Aeromedical Laboratory, Fort Wainwright, Ala.

Rode, Andris, and R. J. Shephard

1973 Fitness of the Canadian Eskimo-The influence of season. Medicine and Science in Sports 5:170-173.

Rogers, Edward S.

1972 The Mistassini Cree. In Hunters and gatherers today, edited by M. G. Bicchieri, pp. 90-137. Holt, Rinehart \& Winston, New York.

Rosenthal, H. L., and J. B. Allison

1951 Some effects of caloric intake on nitrogen balance in dogs. Journal of Nutrition $44: 423-431$. 
Rothwell, N. J., and M. J. Stock

1979 A role for brown adipose tissue in diet-induced thermogenesis. Nature (London) 281:31-35.

Schaefer, Otto

1977 Changing dietary patterns in the Canadian north: Health, social and economic consequences. Journal of the Canadian Dietetic Association 38:17-25.

Shephard, Roy J.

1974 Work physiology and activity patterns of circumpolar Eskimos and Ainu, A synthesis of I.B.P. data. Human Biology 46:263-294.

1978 Human physiological work capacity. International Biological Programme 15. Cambridge Univ. Press, Cambridge.

1980 Work physiology and activity patterns. In The human biology of circumpolar populations, edited by F. A. Milan, pp. 305-338. Cambridge Univ. Press, Cambridge.

Silberbauer, George B.

1981 IIunter and habitat in the central Kalahari desert. Cambridge Univ. Press, Cambridge.

Sim, A. J. W., et al.

1979 Glucose promotes whole-body protein synthesis from infused aminoacids in fasting man. Lancet 1:68-72.

Sinclair, A. R. E., and P. Duncan

1972 Indices of condition in tropical ruminants. East African Wildlife Journal 10: $143-149$.

Smith, Norman S.

1970 Appraisal of condition estimation methods for East African ungulates. East African Wildlife Journal 8:123-129.

Spencer, R. F.

1959 The North Alaskan Eskimo: A study in ecology and society. Bureau of American Ethnology Bulletin 171.

Speth, John D.

1983 Bison kills and bone counts: Decision making by ancient hunters. Univ. of Chicago Press, Chicago.

Spielmann, Katherine A.

1982 Inter-societal food acquisition among egalitarian societies: An ecological study of plains/pueblo interaction in the American Southwest. Unpublished Ph.D. dissertation, Department of Anthropology, University of Michigan.

Stefansson, Vilhjalmur

1944 Arctic manual. Macmillan, New York.

1956 The fat of the land. Macmillan, New York.

Steward, Julian $\mathbf{H}$.

1938 Basin-Plateau aboriginal sociopolitical groups. Bureau of American Ethnology Bulletin 120.

Stockle, A. W., G. L. Doster, and W. R. Davidson

1978 Endogenous fat as an indicator of physical condition of southeastern whitetailed deer. Southeastern Association of Fish and Wildlife Agencies, Conference Proceedings 32:269-279.

Taylor, Clara M., and Orrea F. Pye

1966 Foundations of nutrition (sixth ed.). Macmillan, New York.

Thomas, Alfred Barnaby

1935 After Coronado: Spanish exploration northeast of New Mexico 1696-1727. Univ. of Oklahoma Press, Norman. 
Torún, B., and V. R. Young

1981 Interaction of energy and protein intakes in relation to dietary requirements. In Nutrition in health and disease and international development, edited by A. E. Harper and G. K. Davis, pp. 47-56. Alan R. Less, New York.

Trout, L. E., and J. L. Thiessen

1968 Food habits and condition of mule deer in Owyhee County. Western Association of State Game and Fish Commissioners, Western Proceedings 48:188-200.

Truswell, A. S., and J. D. L. Hansen

1968 Medical and nutritional studies of !Kung Bushmen in northwest Botswana: A preliminary report. South African Medical Journal 42:1338-1339.

Turnbull, Colin $\mathbf{M}$.

1965 The Mbuti pygmies: An ethnographic survey. American Museum of Natural History Anthropological Paper 50(3).

Turner, Jack $C$.

1979 Adaptive strategies of selective fatty acid deposition in the bone marrow of desert bighorn sheep. Comparative Biochemistry and Physiology 62A:599-604.

Watt, B. K., and A. L. Merrill

1963 Composition of foods: Raw, processed, prepared. U.S. Department of Agriculture Handbook 8.

Weiner, January

1973 Dressing percentage, gross body composition and caloric value of the roe-deer. Acta Theriologica 18:209-222.

West, G. C., and D. L. Shaw

1975 Fatty acid composition of dall sheep bone marrow. Comparative Biochemistry and Physiology 50B:599-601.

Wetterstrom, Wilma

1976 The effects of nutrition on population size at Pueblo Arroyo Hondo, New Mexico. Unpublished Ph.D. dissertation, Department of Anthropology, University of Michigan.

Wheat, Joe Ben

1972 The Olsen-Chubbuck Site: a Paleo-Indian bison kill. Society for American Archaeology Memoir 26.

Wilber, C. G., and T. W. Gorski

1955 The lipids in Bison bison. Journal of Mammalogy 36:305-308.

Wilmsen, Edwin N.

1978 Seasonal effects of dietary intake on Kalahari San. Federation Proceedings 37:65-72.

Wing, Elizabeth S., and Antoinette B. Brown

1979 Paleonutrition. Academic Press, New York.

Wo, C. K. W., and H. H. Draper

1975 Vitamin E status of Alaskan Eskimos. American Journal of Clinical Nutrition 28:808-813.

Young, V. R., and D. M. Bier

1981 Protein metabolism and nutritional state in man. Proceedings of the Nutrition Society 40:343-359. 